\title{
SUBJECT INDEX 2018
}

\section{1-Naphthaleneacetic acid}

Effect of nutritional and growth hormonal factors on in vitro regeneration of papaya (Carica papaya L. cv. Red Lady) (Nguyen V.H., Yen C.R. \& Hsieh C.H.) 46: 559-568 (2018)

\section{6-Benzylaminopurine}

Effect of nutritional and growth hormonal factors on in vitro regeneration of papaya (Carica papaya L. cv. Red Lady) (Nguyen V.H., Yen C.R. \& Hsieh C.H.) 46: 559-568 (2018)

\section{Above-ground carbon}

Generic assumption vs. empirical model in stem carbon prediction of Eucalyptus grandis Wall ex. Maiden (Bandara W.A.R.T.W. \& Aththanayake A.M.H.L.) 46: 411-422 (2018)

\section{Abrupt depth configurations}

Numerical modelling of wave transformation over submerged breakwaters using Boussinesq-type models (Ranasinghe R.S.) 46: 369-379 (2018)

\section{Activation energy}

Kissinger method: the sequential approach and DAEM for kinetic study of rubber and gliricidia wood (Perera K.U.C. \& Narayana M.) 46: 187-196 (2018)

\section{Additive}

Genetic analysis of yield and physical traits of spring wheat grain (Muhu-Din Ahmed H.G., Khan A.S., Kashif M. \& Khan S.H.) 46: 23-30 (2018)

\section{Adsorption}

Investigation on adsorption kinetics of heavy metals by rice husk (Priyantha N., Navaratne A.N. \& Kulasooriya T.P.K.) 46: 125-141 (2018)

\section{Agreement}

Use of Mandel's bundle of lines model to improve agreement of a panel of tea tasters (Peiris T.U.S., Walgampaya C.K., Banks D.L., Thattil R.O. \& Abeysinghe I.S.B.) 46: 95-102 (2018)

\section{Agricultural impacts}

Spatio-temporal variation of water quality and bio indicators of the Badulu Oya in Sri Lanka due to catchment disturbances (Gunawardhana W.D.T.M., Jayawardhana J.M.C.K., Udayakumara E.P.N. \& Malavipathirana S.) 46: 51-67 (2018)

\section{Allergen database}

WebAllergen: a web-based database for protein allergenicity prediction (Won S.Y., Baek J.H., Oh J.H., Lee G.S., Kim Y.H. \& Kim C.K.) 46: 233$236(2018)$

\section{Allergenicity prediction}

WebAllergen: a web-based database for protein allergenicity prediction (Won S.Y., Baek J.H., Oh J.H., Lee G.S., Kim Y.H. \& Kim C.K.) 46: 233$236(2018)$

\section{Allium}

Assessing toxicity of two industrial zone effluents reaching Kelani River, Sri Lanka (Hemachandra C.K. \& Pathiratne A.) 46: $539-546$ (2018)

\section{Ant colony optimisation}

An optimal feature selection method using a modified wrapper-based ant colony optimisation (Jameel S. \& Rehman S.U.) 46: 143-151 (2018)

\section{Anti-inflammatory}

Preliminary screening of two marine algae and sea grass harvested from Sri Lankan waters against the LPS-induced inflammatory responses in RAW 264.7 macrophages and in vivo zebrafish embryo model (Fernando I.P.S., Sanjeewa K.K.A., Samarakoon K.W., Lee W.W., Kim H.S., Kim E.A., Ranasinghe P., Gunasekara U.K.D.S.S., Premakumara G.A.S. \& Jeon Y.J.) 46: 117-124 (2018)

\section{Approximation order}

A $\mathrm{C}^{2}$-continuous rational quintic interpolation scheme for curve data with shape control (Hussain M.Z., Hussain M. \& Yameen Z.) 46: $341-354$ $(2018)$

\section{Arboreal tiger beetles}

The forgotten tigers: the arboreal tiger beetles of Sri Lanka (Dangalle C.D.) 46: 241-252 (2018)

\section{Average edge}

Gradual transition detection in shot boundary using gradual curve point (Prabavathy A.K. \& Shree J.D.) 46: 393-398 (2018)

\section{Average time complexity}

Average time complexity analysis of Commentz-Walter algorithm (Dewasurendra S.D. \& Vidanagamachchi S.M.) 46: $547-557$ (2018)

B(E2) values

Calculation of some of the nuclear properties of even-even ${ }^{172-176} \mathrm{Hf}$ isotopes using IBM-1 (Kassim H.H., Mohammed-Ali A.A., Al-Jubbori M.A., Sharrad F.I., Ahmed A.S. \& Hossain I.) 46: 3-10 (2018) 


\section{Bacterial wilt}

Development of a rapid, sensitive and specific DNA-based method to detect Ralstonia solanacearum in potato for quarantine purposes (Perera A.A.U., Weerasena O.V.D.S.J., Dasanayaka P.N. \& Wickramarachchi D.C.) 46: 153-158 (2018)

\section{Batticaloa}

Diet related factors for good glycaemic control among patients with diabetes mellitus in the Teaching Hospital, Batticaloa, Sri Lanka (Kisokanth G., Prathapan S., Indrakumar J. \& Ilankoon I.M.P.S.) 46: 443-451 (2018)

\section{Bay of Bengal}

Interpretation of gravity anomalies over the eighty-five East Ridge in the Bay of Bengal (Tantrigoda D.A. \& Fernando M.M.P.M.) 46: 487-494 (2018)

\section{Bayes estimator}

Bayesian estimation of the mixture of exponentiated inverted Weibull distribution using noninformative and informative priors (Aslam M., Nawaz S., Ali S. \& De Silva S.A.K.P.) 46: 569-586 (2018)

\section{Bg 90 - 2}

Development of heat tolerant introgression lines and preliminary quantitative trait loci (QTL) analysis at flowering stage in Oryza sativa L. (Udawela U.A.K.S., Ananda G.K.S., Karunarathne S.I., Sooriyapathirana S.D.S.S., Li F. \& Liu Z.) 46: 253-270 (2018)

\section{Bias}

Enhancing ratio estimators for estimating population mean using maximum value of auxiliary variable (Abbas N., Abid M., Tahir M., Abbas N. \& Hussain Z.) 46: 453-463 (2018)

\section{Bifidobacteria}

Prebiotic carbohydrate profile and in vivo prebiotic effect of pumpkin (Cucurbita maxima) grown in Sri Lanka (Lokuge G.M.S., Vidanarachchi J.K., Thavarajah P., Siva N., Thavarajah D., Liyanage R., Balasooriya N. \& Alwis J.) 46: 477-485 (2018)

\section{Biplot}

Estimation of genetic diversity in sorghum genotypes of Pakistan (Mumtaz A., Hussain D., Saeed M., Arshad M. \&. Yousaf M.I.) 46: 271-280 (2018)

\section{Boussinesq-type equations}

Numerical modelling of wave transformation over submerged breakwaters using Boussinesq-type models (Ranasinghe R.S.) 46: 369-379 (2018)

B-spline curve

$C^{3}$ cubic trigonometric B-spline curves with a real parameter (Xie W. \& Li J.) 46: 89-94 (2018)

\section{Building materials}

Cradle-to-gate life cycle assessment of energy and carbon of a residential building in Sri Lanka (Kumanayake R.P. \& Luo H.) 46: 355-367 (2018)

$C^{2}$-continuity A

$\mathrm{C}^{2}$-continuous rational quintic interpolation scheme for curve data with shape control (Hussain M.Z., Hussain M. \& Yameen Z.) 46: $341-354$ (2018)

$C^{3}$ continuity

$C^{3}$ cubic trigonometric B-spline curves with a real parameter (Xie W. \& Li J.) 46: 89-94 (2018)

\section{$\mathrm{C}_{3}$ or $\mathrm{C}_{4}$ pasture species}

Root growth responses of parthenium weed and different pasture plants under elevated atmospheric carbon dioxide (Khan N., Hanif Z., Khan I.A., Naveed K., Shabbir A. \& Adkins S.W.) 46: 303-310 (2018)

\section{Cabbage}

Phenotypic variation of cabbage white mold pathogen, Sclerotinia sclerotiorum in the upcountry commercial cabbage fields in Sri Lanka (Mahalingam T., Guruge B.M.A., Somachandra K.P., Jayasekara E.A.E.S.S., Rajapakse C.S.K. \& Attanayake R.N.) 46: 159-164 (2018)

\section{Callus culture}

Comparative morpho-physiological response of in vitro selected somaclones of wheat (Triticum aestivum L.) and explant donor parent to drought stress (Mahmood I., Razzaq A., Qureshi A.A., Qayyum A. \& Baig M.M.Q.) 46: 293-302 (2018)

\section{Carbon sequestration}

Generic assumption vs. empirical model in stem carbon prediction of Eucalyptus grandis Wall ex. Maiden (Bandara W.A.R.T.W. \& Aththanayake A.M.H.L.) 46: 411-422 (2018)

\section{Casein hydrolysate}

Effect of nutritional and growth hormonal factors on in vitro regeneration of papaya (Carica papaya L. cv. Red Lady) (Nguyen V.H., Yen C.R. \& Hsieh C.H.) 46: 559-568 (2018)

\section{Censored data}

Adaptation of the weighted Kaplan-Meier method to time-dependent ROC curves (Sigirli D., Ercan I., Balcin O. \& Kaya E.) 46: 11-21 (2018) 


\section{Chaetomorpha antennina}

Preliminary screening of two marine algae and sea grass harvested from Sri Lankan waters against the LPS-induced inflammatory responses in RAW 264.7 macrophages and in vivo zebrafish embryo model (Fernando I.P.S., Sanjeewa K.K.A., Samarakoon K.W., Lee W.W., Kim H.S., Kim E.A., Ranasinghe P., Gunasekara U.K.D.S.S., Premakumara G.A.S. \& Jeon Y.J.) 46: 117-124 (2018)

\section{Climate change}

Influences of temperature and precipitation on soil moisture in Anuradhapura District (Nawagamuwa U.P., Hornberger G.M. \& Gunda T.) 46: 519526 (2018)

\section{Cluster analysis}

Estimation of genetic diversity in sorghum genotypes of Pakistan (Mumtaz A., Hussain D., Saeed M., Arshad M. \&. Yousaf M.I.) 46: 271-280 (2018)

\section{Coefficient of variation}

Enhancing ratio estimators for estimating population mean using maximum value of auxiliary variable (Abbas N., Abid M., Tahir M., Abbas N. \& Hussain Z.) 46: 453-463 (2018)

\section{Collector network}

Collector cable design based on dynamic line rating for wind energy applications (Wijethunga A.H., Ekanayake J.B. \& Wijayakulasooriya J.V.) 46: $31-40$ (2018)

\section{Colour fastness}

Colour fastness to washing of multi-layered digital prints on textile materials (Kašiković N., Vladić G., Milić N., Novaković D., Milošević R. \& Dedijer S.) 46: 381-391 (2018)

\section{Comet assay}

The anti-genotoxic effect of some lichenic acids (Kizil H.E., Ceker S., Capik O. \& Agar G.) 46: $227-231$ (2018)

\section{Commentz-Walter}

Average time complexity analysis of Commentz-Walter algorithm (Dewasurendra S.D. \& Vidanagamachchi S.M.) 46: 547-557 (2018)

\section{Compressive strength}

Potential use of recycled construction and demolition waste aggregates for non-structural concrete applications (Jayakody S., Zimar A.M.Z. \& Ranaweera R.A.L.M.) 46: 205-216 (2018)

\section{Connectivity indices}

Some topological indices of the family of nanostructures of polycyclic aromatic hydrocarbons (PAHs) (Soleimani N., Mohseni E., Maleki N. \& Imani N.) 46: 81-88 (2018)

\section{Construction and demolition}

Potential use of recycled construction and demolition waste aggregates for non-structural concrete applications (Jayakody S., Zimar A.M.Z. \& Ranaweera R.A.L.M.) 46: 205-216 (2018)

\section{Control}

A mathematical model with control to analyse the dynamics of dengue disease transmission in urban Colombo (Wickramaarachchi W.P.T.M. \& Perera S.S.N.) 46: 41-49 (2018)

\section{Cradle-to-gate}

Cradle-to-gate life cycle assessment of energy and carbon of a residential building in Sri Lanka (Kumanayake R.P. \& Luo H.) 46: $355-367$ (2018)

\section{Cubic rank transmutation map}

A new statistical distribution: cubic rank transmuted Kumaraswamy distribution and its properties (Saraçoğlu B. \& Tanış C.) 46: 505-518 (2018)

\section{Cubic rank transmuted Kumaraswamy distribution}

A new statistical distribution: cubic rank transmuted Kumaraswamy distribution and its properties (Saraçoğlu B. \& Tanış C.) 46: 505-518 (2018)

\section{Cut method}

Some topological indices of the family of nanostructures of polycyclic aromatic hydrocarbons (PAHs) (Soleimani N., Mohseni E., Maleki N. \& Imani N.) 46: 81-88 (2018)

\section{Cyber security}

Two-layer malicious network flow detection system with sparse linear model based feature selection (Catak F.O.) 46: 601-612 (2018)

\section{Dengue}

A mathematical model with control to analyse the dynamics of dengue disease transmission in urban Colombo (Wickramaarachchi W.P.T.M. \& Perera S.S.N.) 46: 41-49 (2018)

\section{Density functional theory}

Synthesis and characterisation of two new bicyclic oxazolidines and investigation of their optoelectronic properties using density functional theory (Abbas G., Irfan A., Hameed S., Al-Sehemi A.G., Jin R. \& Tang S.) 46: 197-204 (2018) 
Diabetes mellitus

Diet related factors for good glycaemic control among patients with diabetes mellitus in the Teaching Hospital, Batticaloa, Sri Lanka (Kisokanth G., Prathapan S., Indrakumar J. \& Ilankoon I.M.P.S.) 46: 443-451 (2018)

Dielectric measurement

An efficient algorithm to calculate relative permittivity from multilayered stripline based measurements at microwave frequencies (Gunawardena A.U.A.W.) 46: 103-108 (2018)

\section{Dietary practice}

Diet related factors for good glycaemic control among patients with diabetes mellitus in the Teaching Hospital, Batticaloa, Sri Lanka (Kisokanth G., Prathapan S., Indrakumar J. \& Ilankoon I.M.P.S.) 46: 443-451 (2018)

\section{Diffractaic acid}

The anti-genotoxic effect of some lichenic acids (Kizil H.E., Ceker S., Capik O. \& Agar G.) 46: 227-231 (2018)

\section{Digital printing}

Colour fastness to washing of multi-layered digital prints on textile materials (Kašiković N., Vladić G., Milić N., Novaković D., Milošević R. \& Dedijer S.) 46: 381-391 (2018)

\section{Discriminant analysis}

Morphometry as a tool in species identification: a study with special reference to species of the genus Mycalesis (Lepidoptera: Nymphalidae) (Goonesekera K., van der Poorten G. \& Ranawaka G.R.) 46: 311-328 (2018)

\section{Dusty fluid}

Convective heat transfer in a dusty ferromagnetic fluid over a stretching surface with prescribed surface temperature/heat flux including heat source/ sink (Majeed A., Zeeshan A. \& Gorla R.S.R.) 46: 399-409 (2018)

\section{Dynamic line rating}

Collector cable design based on dynamic line rating for wind energy applications (Wijethunga A.H., Ekanayake J.B. \& Wijayakulasooriya J.V.) 46 $31-40(2018)$

\section{Eighty-five East Ridge}

Interpretation of gravity anomalies over the eighty-five East Ridge in the Bay of Bengal (Tantrigoda D.A. \& Fernando M.M.P.M.) 46: 487-494 (2018)

Elevated atmospheric $\mathrm{CO}_{2}$

Root growth responses of parthenium weed and different pasture plants under elevated atmospheric carbon dioxide (Khan N., Hanif Z., Khan I.A., Naveed K., Shabbir A. \& Adkins S.W.) 46: 303-310 (2018)

\section{Embodied carbon}

Cradle-to-gate life cycle assessment of energy and carbon of a residential building in Sri Lanka (Kumanayake R.P. \& Luo H.) 46: 355-367 (2018)

\section{Embodied energy}

Cradle-to-gate life cycle assessment of energy and carbon of a residential building in Sri Lanka (Kumanayake R.P. \& Luo H.) 46: $355-367$ (2018)

\section{Energy dissipation}

Numerical modelling of wave transformation over submerged breakwaters using Boussinesq-type models (Ranasinghe R.S.) 46: 369-379 (2018)

\section{Energy level}

Calculation of some of the nuclear properties of even-even ${ }^{172-176} \mathrm{Hf}$ isotopes using IBM-1 (Kassim H.H., Mohammed-Ali A.A., Al-Jubbori M.A., Sharrad F.I., Ahmed A.S. \& Hossain I.) 46: 3-10 (2018)

\section{Ethephon concentration}

Effect of ethephon stimulation on natural rubber latex properties; new insight into ethephon stimulation (Attanayake A.P., Karunanayake L. \& Nilmini A.H.R.L.) 46: 179-185 (2018)

\section{Eucalyptus grandis}

Generic assumption vs. empirical model in stem carbon prediction of Eucalyptus grandis Wall ex. Maiden (Bandara W.A.R.T.W. \& Aththanayake A.M.H.L.) 46: 411-422 (2018)

\section{Expected shift length}

Average time complexity analysis of Commentz-Walter algorithm (Dewasurendra S.D. \& Vidanagamachchi S.M.) 46: 547-557 (2018)

$\mathbf{f}_{0} \mathbf{F}_{2}$ Modelling the effects of solar activity on the ionospheric $\mathrm{F}_{2}$ critical frequency over Wakkanai (Mushtaq M., Afridi F.A.K., Alam S.N. \& Fatima H.) 46: $527-538(2018)$

\section{Fatty acid methyl esters}

Optimising a solvent system for lipid extraction from cyanobacterium Microcystis spp.: future perspective for biodiesel production (Madusanka D.A.T. \& Manage P.M.) 46: 217-225 (2018) 
Feature selection

An optimal feature selection method using a modified wrapper-based ant colony optimisation (Jameel S. \& Rehman S.U.) 46: 143-151 (2018)

\section{Feature selection}

Two-layer malicious network flow detection system with sparse linear model based feature selection (Catak F.O.) 46: 601-612 (2018)

\section{Ferro-particles}

Convective heat transfer in a dusty ferromagnetic fluid over a stretching surface with prescribed surface temperature/heat flux including heat source/ sink (Majeed A., Zeeshan A. \& Gorla R.S.R.) 46: 399-409 (2018)

\section{Flood monitoring}

An automated image dehazing method for flood detection to improve flood alert monitoring system (Tseng C.H., Chen L.C., Wu J.H., Lin F.P. \& Sheu R.K.) 46: 329-339 (2018)

\section{Forest plantations}

Generic assumption vs. empirical model in stem carbon prediction of Eucalyptus grandis Wall ex. Maiden (Bandara W.A.R.T.W. \& Aththanayake A.M.H.L.) 46: 411-422 (2018)

\section{Free parameters}

A $\mathrm{C}^{2}$-continuous rational quintic interpolation scheme for curve data with shape control (Hussain M.Z., Hussain M. \& Yameen Z.) 46: 341-354 (2018)

\section{Fuzzifying ternary semigroup}

Implication-based fuzzy ternary subsemigroups in ternary semigroups (Rehman N.) 46: 423-430 (2018)

\section{Fuzzy set theory}

A mathematical model with control to analyse the dynamics of dengue disease transmission in urban Colombo (Wickramaarachchi W.P.T.M. \& Perera S.S.N.) 46: 41-49 (2018)

\section{Fuzzy ternary subsemigroup}

Implication-based fuzzy ternary subsemigroups in ternary semigroups (Rehman N.) 46: 423-430 (2018)

\section{Generalised roughness}

Generalised roughness in ( $€, \in V q)$-fuzzy substructures of LA-semigroups (Rehman N., Shah N., Ali M.I. \& Ali A.) 46: 465-473 (2018)

\section{Generation}

Genetic analysis of yield and physical traits of spring wheat grain (Muhu-Din Ahmed H.G., Khan A.S., Kashif M. \& Khan S.H.) 46: 23-30 (2018)

\section{Genetic diversity}

Estimation of genetic diversity in sorghum genotypes of Pakistan (Mumtaz A., Hussain D., Saeed M., Arshad M. \&. Yousaf M.I.) 46: 271-280 (2018)

\section{Geomagnetic $A_{p}$ index}

Modelling the effects of solar activity on the ionospheric $\mathrm{F}_{2}$ critical frequency over Wakkanai (Mushtaq M., Afridi F.A.K., Alam S.N. \& Fatima H.) 46: $527-538(2018)$

\section{Global warming}

Development of heat tolerant introgression lines and preliminary quantitative trait loci (QTL) analysis at flowering stage in Oryza sativa L. (Udawela U.A.K.S., Ananda G.K.S., Karunarathne S.I., Sooriyapathirana S.D.S.S., Li F. \& Liu Z.) 46: 253-270 (2018)

\section{Glycation}

In vitro antiglycation and hypoglycaemic effects of Syzygium cumini leaf extracts (Perera H.K.I., Poongunran J., Premadasa W.K.V.K. \& Jayasinghe J.A.V.P.) 46: 281-291 (2018)

\section{Good glycaemic control}

Diet related factors for good glycaemic control among patients with diabetes mellitus in the Teaching Hospital, Batticaloa, Sri Lanka (Kisokanth G., Prathapan S., Indrakumar J. \& Ilankoon I.M.P.S.) 46: 443-451 (2018)

\section{Gracilaria edulis}

Preliminary screening of two marine algae and sea grass harvested from Sri Lankan waters against the LPS-induced inflammatory responses in RAW 264.7 macrophages and in vivo zebrafish embryo model (Fernando I.P.S., Sanjeewa K.K.A., Samarakoon K.W., Lee W.W., Kim H.S., Kim E.A., Ranasinghe P., Gunasekara U.K.D.S.S., Premakumara G.A.S. \& Jeon Y.J.) 46: 117-124 (2018)

\section{Gradual curve}

Gradual transition detection in shot boundary using gradual curve point (Prabavathy A.K. \& Shree J.D.) 46: 393-398 (2018)

\section{Gradual transition}

Gradual transition detection in shot boundary using gradual curve point (Prabavathy A.K. \& Shree J.D.) 46: 393-398 (2018)

\section{Grain}

Genetic analysis of yield and physical traits of spring wheat grain (Muhu-Din Ahmed H.G., Khan A.S., Kashif M. \& Khan S.H.) 46: 23-30 (2018) 
Gravity anomaly

Interpretation of gravity anomalies over the eighty-five East Ridge in the Bay of Bengal (Tantrigoda D.A. \& Fernando M.M.P.M.) 46: 487-494 (2018)

Growth

Growth responses of Lantana (Lantana camara L.) varieties to varying water availability and light conditions (Gunasekara C.J. \& Ranwala S.M.W.) 46: 69-79 (2018)

\section{Half-normal distribution}

Bayesian inference from the mixture of half-normal distributions under censoring (Sindhu T.N., Khan H.M.R., Hussain Z. \& Al-Zahrani B.) 46: 587-600 (2018)

\section{Hazard mitigation}

An automated image dehazing method for flood detection to improve flood alert monitoring system (Tseng C.H., Chen L.C., Wu J.H., Lin F.P. \& Sheu R.K.) 46: 329-339 (2018)

\section{Hazard rate function}

Bayesian inference from the mixture of half-normal distributions under censoring (Sindhu T.N., Khan H.M.R., Hussain Z. \& Al-Zahrani B.) 46: 587-600 (2018)

\section{Haze imaging model}

An automated image dehazing method for flood detection to improve flood alert monitoring system (Tseng C.H., Chen L.C., Wu J.H., Lin F.P. \& Sheu R.K.) 46: 329-339 (2018)

\section{Heat source/sink}

Convective heat transfer in a dusty ferromagnetic fluid over a stretching surface with prescribed surface temperature/heat flux including heat source/ sink (Majeed A., Zeeshan A. \& Gorla R.S.R.) 46: 399-409 (2018)

\section{Heat stress on rice}

Development of heat tolerant introgression lines and preliminary quantitative trait loci (QTL) analysis at flowering stage in Oryza sativa L. (Udawela U.A.K.S., Ananda G.K.S., Karunarathne S.I., Sooriyapathirana S.D.S.S., Li F. \& Liu Z.) 46: 253-270 (2018)

\section{Heat tolerant QTLs}

Development of heat tolerant introgression lines and preliminary quantitative trait loci (QTL) analysis at flowering stage in Oryza sativa L. (Udawela U.A.K.S., Ananda G.K.S., Karunarathne S.I., Sooriyapathirana S.D.S.S., Li F. \& Liu Z.) 46: 253-270 (2018)

\section{Heavy metals}

Investigation on adsorption kinetics of heavy metals by rice husk (Priyantha N., Navaratne A.N. \& Kulasooriya T.P.K.) 46: 125-141 (2018)

\section{Hevea brasiliensis}

Effect of ethephon stimulation on natural rubber latex properties; new insight into ethephon stimulation (Attanayake A.P., Karunanayake L. \& Nilmini A.H.R.L.) 46: 179-185 (2018)

\section{Historical records}

The forgotten tigers: the arboreal tiger beetles of Sri Lanka (Dangalle C.D.) 46: 241-252 (2018)

\section{Hybrid rice}

Development of heat tolerant introgression lines and preliminary quantitative trait loci (QTL) analysis at flowering stage in Oryza sativa L. (Udawela U.A.K.S., Ananda G.K.S., Karunarathne S.I., Sooriyapathirana S.D.S.S., Li F. \& Liu Z.) 46: 253-270 (2018)

\section{Image dehazing}

An automated image dehazing method for flood detection to improve flood alert monitoring system (Tseng C.H., Chen L.C., Wu J.H., Lin F.P. \& Sheu R.K.) 46: 329-339 (2018)

\section{Indian Ocean}

Interpretation of gravity anomalies over the eighty-five East Ridge in the Bay of Bengal (Tantrigoda D.A. \& Fernando M.M.P.M.) 46: 487-494 (2018)

\section{Indole-3-butyric acid}

Effect of nutritional and growth hormonal factors on in vitro regeneration of papaya (Carica papaya L. cv. Red Lady) (Nguyen V.H., Yen C.R. \& Hsieh C.H.) 46: 559-568 (2018)

\section{Industrial zone effluent}

Assessing toxicity of two industrial zone effluents reaching Kelani River, Sri Lanka (Hemachandra C.K. \& Pathiratne A.) 46: 539-546 (2018)

\section{Informative prior}

Bayesian estimation of the mixture of exponentiated inverted Weibull distribution using noninformative and informative priors (Aslam M., Nawaz S., Ali S. \& De Silva S.A.K.P.) 46: 569-586 (2018)

\section{Inhibitors}

In vitro antiglycation and hypoglycaemic effects of Syzygium cumini leaf extracts (Perera H.K.I., Poongunran J., Premadasa W.K.V.K. \& Jayasinghe J.A.V.P.) 46: 281-291 (2018) 
Ink layers

Colour fastness to washing of multi-layered digital prints on textile materials (Kašiković N., Vladić G., Milić N., Novaković D., Milošević R. \& Dedijer S.) 46: 381-391 (2018)

\section{Interacting boson model}

Calculation of some of the nuclear properties of even-even ${ }^{172-176} \mathrm{Hf}$ isotopes using IBM-1 (Kassim H.H., Mohammed-Ali A.A., Al-Jubbori M.A., Sharrad F.I., Ahmed A.S. \& Hossain I.) 46: 3-10 (2018)

\section{Intra-particle diffusion model}

Investigation on adsorption kinetics of heavy metals by rice husk (Priyantha N., Navaratne A.N. \& Kulasooriya T.P.K.) 46: 125-141 (2018)

\section{Ionosphere}

Modelling the effects of solar activity on the ionospheric $\mathrm{F}_{2}$ critical frequency over Wakkanai (Mushtaq M., Afridi F.A.K., Alam S.N. \& Fatima H.) 46: $527-538$ (2018)

\section{Kelani River}

Assessing toxicity of two industrial zone effluents reaching Kelani River, Sri Lanka (Hemachandra C.K. \& Pathiratne A.) 46: $539-546$ (2018)

\section{Kinetics}

Investigation on adsorption kinetics of heavy metals by rice husk (Priyantha N., Navaratne A.N. \& Kulasooriya T.P.K.) 46: 125-141 (2018)

\section{Lactic acid bacteria}

Prebiotic carbohydrate profile and in vivo prebiotic effect of pumpkin (Cucurbita maxima) grown in Sri Lanka (Lokuge G.M.S., Vidanarachchi J.K., Thavarajah P., Siva N., Thavarajah D., Liyanage R., Balasooriya N. \& Alwis J.) 46: 477-485 (2018)

\section{Lantana}

Growth responses of Lantana (Lantana camara L.) varieties to varying water availability and light conditions (Gunasekara C.J. \& Ranwala S.M.W.) 46: 69-79 (2018)

\section{LA-semigroups}

Generalised roughness in $(\in, \in V q)$-fuzzy substructures of LA-semigroups (Rehman N., Shah N., Ali M.I. \& Ali A.) 46: 465-473 (2018)

\section{Latex quality}

Effect of ethephon stimulation on natural rubber latex properties; new insight into ethephon stimulation (Attanayake A.P., Karunanayake L. \& Nilmini A.H.R.L.) 46: 179-185 (2018)

\section{Lecanoric acid}

The anti-genotoxic effect of some lichenic acids (Kizil H.E., Ceker S., Capik O. \& Agar G.) 46: 227-231 (2018)

\section{Lichen compounds}

The anti-genotoxic effect of some lichenic acids (Kizil H.E., Ceker S., Capik O. \& Agar G.) 46: 227-231 (2018)

\section{Life cycle assessment}

Cradle-to-gate life cycle assessment of energy and carbon of a residential building in Sri Lanka (Kumanayake R.P. \& Luo H.) 46: 355-367 (2018)

Light conditions

Growth responses of Lantana (Lantana camara L.) varieties to varying water availability and light conditions (Gunasekara C.J. \& Ranwala S.M.W.) 46: 69-79 (2018)

\section{Lipid extraction solvent systems}

Optimising a solvent system for lipid extraction from cyanobacterium Microcystis spp.: future perspective for biodiesel production (Madusanka D.A.T. \& Manage P.M.) 46: 217-225 (2018)

\section{Lisotrigona}

Rediscovery of Tetragonula praeterita after 1860: an unremarked common stingless bee endemic to Sri Lanka (Silva T.H.S.E., Diyes G.C.P., Karunaratne W.A.I. P. \& Edirisinghe J.P.) 46: 109-113 (2018)

\section{Lobaric acid}

The anti-genotoxic effect of some lichenic acids (Kizil H.E., Ceker S., Capik O. \& Agar G.) 46: 227-231 (2018)

\section{Loss function}

Bayesian estimation of the mixture of exponentiated inverted Weibull distribution using noninformative and informative priors (Aslam M., Nawaz S., Ali S. \& De Silva S.A.K.P.) 46: 569-586 (2018)

\section{Loss functions}

Bayesian inference from the mixture of half-normal distributions under censoring (Sindhu T.N., Khan H.M.R., Hussain Z. \& Al-Zahrani B.) 46: 587-600 (2018)

\section{Lower record values}

Record values of ratio of Weibull random variables (Al-Zahrani B., Shahbaz S.H. \& Shahbaz M.Q.) 46: 165-178 (2018) 
Macroinvertebrate indices

Spatio-temporal variation of water quality and bio indicators of the Badulu Oya in Sri Lanka due to catchment disturbances (Gunawardhana W.D.T.M., Jayawardhana J.M.C.K., Udayakumara E.P.N. \& Malavipathirana S.) 46: 51-67 (2018)

\section{Magnetic dipole}

Convective heat transfer in a dusty ferromagnetic fluid over a stretching surface with prescribed surface temperature/heat flux including heat source/ sink (Majeed A., Zeeshan A. \& Gorla R.S.R.) 46: 399-409 (2018)

Malicious network flow

Two-layer malicious network flow detection system with sparse linear model based feature selection (Catak F.O.) 46: 601-612 (2018)

\section{Mandel's bundle of lines model}

Use of Mandel's bundle of lines model to improve agreement of a panel of tea tasters (Peiris T.U.S., Walgampaya C.K., Banks D.L., Thattil R.O. \& Abeysinghe I.S.B.) 46: 95-102 (2018)

\section{Marker assisted breeding of rice}

Identification of Pupl QTL linked DNA marker haplotypes for molecular breeding of phosphorous deficiency tolerant rice varieties (Aluwihare Y.C., Chamikara M.D.M., Dissanayake D.R.R.P., Karunarathne S.I., Ananda G.K.S., Kannangara S.K., Madhukalpani O.V.S., Sirisena D.N., Samarasinghe W.L.G. \& Sooriyapathirana S.D.S.S.) 46: 495-504 (2018)

\section{Mathematical models}

A mathematical model with control to analyse the dynamics of dengue disease transmission in urban Colombo (Wickramaarachchi W.P.T.M. \& Perera S.S.N.) 46: 41-49 (2018)

\section{Maximum likelihood estimation}

A new statistical distribution: cubic rank transmuted Kumaraswamy distribution and its properties (Saraçoğlu B. \& Tanış C.) 46: 505-518 (2018)

\section{Maximum value}

Enhancing ratio estimators for estimating population mean using maximum value of auxiliary variable (Abbas N., Abid M., Tahir M., Abbas N. \& Hussain Z.) 46: 453-463 (2018)

\section{Meteorological data}

Influences of temperature and precipitation on soil moisture in Anuradhapura District (Nawagamuwa U.P., Hornberger G.M. \& Gunda T.) 46: 519$526(2018)$

\section{Microcystis spp.}

Optimising a solvent system for lipid extraction from cyanobacterium Microcystis spp.: future perspective for biodiesel production (Madusanka D.A.T. \& Manage P.M.) 46: 217-225 (2018)

Mid-latitude

Modelling the effects of solar activity on the ionospheric $\mathrm{F}_{2}$ critical frequency over Wakkanai (Mushtaq M., Afridi F.A.K., Alam S.N. \& Fatima H.) 46: $527-538(2018)$

\section{Mixed convection}

Convective heat transfer in a dusty ferromagnetic fluid over a stretching surface with prescribed surface temperature/heat flux including heat source/ sink (Majeed A., Zeeshan A. \& Gorla R.S.R.) 46: 399-409 (2018)

\section{Mixture distribution}

Bayesian estimation of the mixture of exponentiated inverted Weibull distribution using noninformative and informative priors (Aslam M., Nawaz S., Ali S. \& De Silva S.A.K.P.) 46: 569-586 (2018)

\section{Mixture distribution}

Bayesian inference from the mixture of half-normal distributions under censoring (Sindhu T.N., Khan H.M.R., Hussain Z. \& Al-Zahrani B.) 46: 587-600 (2018)

\section{Modified Gompertz}

A PEG 4000-degrading and hexavalent molybdenum-reducing Pseudomonas putida strain Egypt-15 (AbdEl-Mongy M.A., Aqlima S.A., Shukor M.S., Hussein S., Ling A.P.K. \& Shukor M.Y.) 46: 431-442 (2018)

\section{Molybdenum blue}

A PEG 4000-degrading and hexavalent molybdenum-reducing Pseudomonas putida strain Egypt-15 (AbdEl-Mongy M.A., Aqlima S.A., Shukor M.S., Hussein S., Ling A.P.K. \& Shukor M.Y.) 46: 431-442 (2018)

\section{Molybdenum-reducing bacteria}

A PEG 4000-degrading and hexavalent molybdenum-reducing Pseudomonas putida strain Egypt-15 (AbdEl-Mongy M.A., Aqlima S.A., Shukor M.S., Hussein S., Ling A.P.K. \& Shukor M.Y.) 46: 431-442 (2018)

\section{Monte-Carlo simulation}

A new statistical distribution: cubic rank transmuted Kumaraswamy distribution and its properties (Saraçoğlu B. \& Tanış C.) 46: 505-518 (2018) 
Morphology

Morphometry as a tool in species identification: a study with special reference to species of the genus Mycalesis (Lepidoptera: Nymphalidae) (Goonesekera K., van der Poorten G. \& Ranawaka G.R.) 46: 311-328 (2018)

\section{MS medium}

Effect of nutritional and growth hormonal factors on in vitro regeneration of papaya (Carica papaya L. cv. Red Lady) (Nguyen V.H., Yen C.R. \& Hsieh C.H.) 46: 559-568 (2018)

Multi-layer A

An efficient algorithm to calculate relative permittivity from multilayered stripline based measurements at microwave frequencies (Gunawardena A.U.A.W.) 46: 103-108 (2018)

\section{Multiple pattern matching}

Average time complexity analysis of Commentz-Walter algorithm (Dewasurendra S.D. \& Vidanagamachchi S.M.) 46: $547-557$ (2018)

\section{Mycalesis}

Morphometry as a tool in species identification: a study with special reference to species of the genus Mycalesis (Lepidoptera: Nymphalidae) (Goonesekera K., van der Poorten G. \& Ranawaka G.R.) 46: 311-328 (2018)

\section{Nanostructures}

Some topological indices of the family of nanostructures of polycyclic aromatic hydrocarbons (PAHs) (Soleimani N., Mohseni E., Maleki N. \& Imani N.) 46: 81-88 (2018)

\section{Newton Raphson}

An efficient algorithm to calculate relative permittivity from multilayered stripline based measurements at microwave frequencies (Gunawardena A.U.A.W.) 46: 103-108 (2018)

\section{Noninformative prior}

Bayesian estimation of the mixture of exponentiated inverted Weibull distribution using noninformative and informative priors (Aslam M., Nawaz S., Ali S. \& De Silva S.A.K.P.) 46: 569-586 (2018)

\section{Non-structural concrete}

Potential use of recycled construction and demolition waste aggregates for non-structural concrete applications (Jayakody S., Zimar A.M.Z. \& Ranaweera R.A.L.M.) 46: 205-216 (2018)

\section{Optoelectronic properties}

Synthesis and characterisation of two new bicyclic oxazolidines and investigation of their optoelectronic properties using density functional theory (Abbas G., Irfan A., Hameed S., Al-Sehemi A.G., Jin R. \& Tang S.) 46: 197-204 (2018)

\section{Osmotic stress}

Comparative morpho-physiological response of in vitro selected somaclones of wheat (Triticum aestivum L.) and explant donor parent to drought stress (Mahmood I., Razzaq A., Qureshi A.A., Qayyum A. \& Baig M.M.Q.) 46: 293-302 (2018)

\section{Paddy production}

Influences of temperature and precipitation on soil moisture in Anuradhapura District (Nawagamuwa U.P., Hornberger G.M. \& Gunda T.) 46: 519$526(2018)$

\section{Parthenium weed}

Root growth responses of parthenium weed and different pasture plants under elevated atmospheric carbon dioxide (Khan N., Hanif Z., Khan I.A., Naveed K., Shabbir A. \& Adkins S.W.) 46: 303-310 (2018)

PCA

Estimation of genetic diversity in sorghum genotypes of Pakistan (Mumtaz A., Hussain D., Saeed M., Arshad M. \&. Yousaf M.I.) 46: 271-280 (2018)

\section{PCR}

Development of a rapid, sensitive and specific DNA-based method to detect Ralstonia solanacearum in potato for quarantine purposes (Perera A.A.U., Weerasena O.V.D.S.J., Dasanayaka P.N. \& Wickramarachchi D.C.) 46: 153-158 (2018)

\section{Permittivity}

An efficient algorithm to calculate relative permittivity from multilayered stripline based measurements at microwave frequencies (Gunawardena A.U.A.W.) 46: 103-108 (2018)

\section{Phenotypic variation}

Phenotypic variation of cabbage white mold pathogen, Sclerotinia sclerotiorum in the upcountry commercial cabbage fields in Sri Lanka (Mahalingam T., Guruge B.M.A., Somachandra K.P., Jayasekara E.A.E.S.S., Rajapakse C.S.K. \& Attanayake R.N.) 46: 159-164 (2018)

\section{Phosphorous uptake}

Identification of Pup1 QTL linked DNA marker haplotypes for molecular breeding of phosphorous deficiency tolerant rice varieties (Aluwihare Y.C., Chamikara M.D.M., Dissanayake D.R.R.P., Karunarathne S.I., Ananda G.K.S., Kannangara S.K., Madhukalpani O.V.S., Sirisena D.N., Samarasinghe W.L.G. \& Sooriyapathirana S.D.S.S.) 46: 495-504 (2018) 
Pi index

Some topological indices of the family of nanostructures of polycyclic aromatic hydrocarbons (PAHs) (Soleimani N., Mohseni E., Maleki N. \& Imani N.) 46: 81-88 (2018)

Pig

Prebiotic carbohydrate profile and in vivo prebiotic effect of pumpkin (Cucurbita maxima) grown in Sri Lanka (Lokuge G.M.S., Vidanarachchi J.K., Thavarajah P., Siva N., Thavarajah D., Liyanage R., Balasooriya N. \& Alwis J.) 46: 477-485 (2018)

Plant physiology

Comparative morpho-physiological response of in vitro selected somaclones of wheat (Triticum aestivum L.) and explant donor parent to drought stress (Mahmood I., Razzaq A., Qureshi A.A., Qayyum A. \& Baig M.M.Q.) 46: 293-302 (2018)

Polyester

Colour fastness to washing of multi-layered digital prints on textile materials (Kašiković N., Vladić G., Milić N., Novaković D., Milošević R. \& Dedijer S.) 46: 381-391 (2018)

\section{Polyethylene glycol biodegradation}

A PEG 4000-degrading and hexavalent molybdenum-reducing Pseudomonas putida strain Egypt-15 (AbdEl-Mongy M.A, Aqlima S.A., Shukor M.S., Hussein S., Ling A.P.K. \& Shukor M.Y.) 46: 431-442 (2018)

\section{Positive and range restricted data}

A $\mathrm{C}^{2}$-continuous rational quintic interpolation scheme for curve data with shape control (Hussain M.Z., Hussain M. \& Yameen Z.) 46: 341-354 (2018)

\section{Posterior distribution}

Bayesian estimation of the mixture of exponentiated inverted Weibull distribution using noninformative and informative priors (Aslam M., Nawaz S., Ali S. \& De Silva S.A.K.P.) 46: 569-586 (2018)

\section{Posterior risk}

Bayesian inference from the mixture of half-normal distributions under censoring (Sindhu T.N., Khan H.M.R., Hussain Z. \& Al-Zahrani B.) 46: 587-600 (2018)

\section{Potential energy}

Calculation of some of the nuclear properties of even-even ${ }^{172-176} \mathrm{Hf}$ isotopes using IBM-1 (Kassim H.H., Mohammed-Ali A.A., Al-Jubbori M.A., Sharrad F.I., Ahmed A.S. \& Hossain I.) 46: 3-10 (2018)

\section{Prebiotic carbohydrates}

Prebiotic carbohydrate profile and in vivo prebiotic effect of pumpkin (Cucurbita maxima) grown in Sri Lanka (Lokuge G.M.S., Vidanarachchi J.K., Thavarajah P., Siva N., Thavarajah D., Liyanage R., Balasooriya N. \& Alwis J.) 46: 477-485 (2018)

\section{Precision and recall}

Gradual transition detection in shot boundary using gradual curve point (Prabavathy A.K. \& Shree J.D.) 46: 393-398 (2018)

\section{Pre-exponential factor}

Kissinger method: the sequential approach and DAEM for kinetic study of rubber and gliricidia wood (Perera K.U.C. \& Narayana M.) 46: 187-196 (2018)

\section{Pseudomonas putida strain Egypt-15}

A PEG 4000-degrading and hexavalent molybdenum-reducing Pseudomonas putida strain Egypt-15 (AbdEl-Mongy M.A., Aqlima S.A., Shukor M.S., Hussein S., Ling A.P.K. \& Shukor M.Y.) 46: 431-442 (2018)

\section{Pumpkin}

Prebiotic carbohydrate profile and in vivo prebiotic effect of pumpkin (Cucurbita maxima) grown in Sri Lanka (Lokuge G.M.S., Vidanarachchi J.K., Thavarajah P., Siva N., Thavarajah D., Liyanage R., Balasooriya N. \& Alwis J.) 46: 477-485 (2018)

\section{Quadrupole moment}

Calculation of some of the nuclear properties of even-even ${ }^{172-176}$ Hf isotopes using IBM-1 (Kassim H.H., Mohammed-Ali A.A., Al-Jubbori M.A., Sharrad F.I., Ahmed A.S. \& Hossain I.) 46: 3-10 (2018)

\section{Quarantine pest}

Development of a rapid, sensitive and specific DNA-based method to detect Ralstonia solanacearum in potato for quarantine purposes (Perera A.A.U., Weerasena O.V.D.S.J., Dasanayaka P.N. \& Wickramarachchi D.C.) 46: 153-158 (2018)

\section{Ralstonia solanacearum}

Development of a rapid, sensitive and specific DNA-based method to detect Ralstonia solanacearum in potato for quarantine purposes (Perera A.A.U., Weerasena O.V.D.S.J., Dasanayaka P.N. \& Wickramarachchi D.C.) 46: 153-158 (2018)

\section{Ratio estimator}

Enhancing ratio estimators for estimating population mean using maximum value of auxiliary variable (Abbas N., Abid M., Tahir M., Abbas N. \& Hussain Z.) 46: 453-463 (2018) 
Rational quantic function

A $\mathrm{C}^{2}$-continuous rational quintic interpolation scheme for curve data with shape control (Hussain M.Z., Hussain M. \& Yameen Z.) 46: 341-354 (2018)

RAW 264.7 macrophages

Preliminary screening of two marine algae and sea grass harvested from Sri Lankan waters against the LPS-induced inflammatory responses in RAW 264.7 macrophages and in vivo zebrafish embryo model (Fernando I.P.S., Sanjeewa K.K.A., Samarakoon K.W., Lee W.W., Kim H.S., Kim E.A., Ranasinghe P., Gunasekara U.K.D.S.S., Premakumara G.A.S. \& Jeon Y.J.) 46: 117-124 (2018)

\section{Recurrence relations}

Record values of ratio of Weibull random variables (Al-Zahrani B., Shahbaz S.H. \& Shahbaz M.Q.) 46: 165-178 (2018)

\section{Regeneration}

Comparative morpho-physiological response of in vitro selected somaclones of wheat (Triticum aestivum L.) and explant donor parent to drought stress (Mahmood I., Razzaq A., Qureshi A.A., Qayyum A. \& Baig M.M.Q.) 46: 293-302 (2018)

\section{Reliability function}

Bayesian inference from the mixture of half-normal distributions under censoring (Sindhu T.N., Khan H.M.R., Hussain Z. \& Al-Zahrani B.) 46: 587-600 (2018)

\section{Reliability}

Use of Mandel's bundle of lines model to improve agreement of a panel of tea tasters (Peiris T.U.S., Walgampaya C.K., Banks D.L., Thattil R.O. \& Abeysinghe I.S.B.) 46: 95-102 (2018)

\section{Rice breeding in Sri Lanka}

Identification of Pupl QTL linked DNA marker haplotypes for molecular breeding of phosphorous deficiency tolerant rice varieties (Aluwihare Y.C., Chamikara M.D.M., Dissanayake D.R.R.P., Karunarathne S.I., Ananda G.K.S., Kannangara S.K., Madhukalpani O.V.S., Sirisena D.N., Samarasinghe W.L.G. \& Sooriyapathirana S.D.S.S.) 46: 495-504 (2018)

\section{Rice husk}

Investigation on adsorption kinetics of heavy metals by rice husk (Priyantha N., Navaratne A.N. \& Kulasooriya T.P.K.) 46: 125-141 (2018)

\section{Rice landraces}

Identification of Pup1 QTL linked DNA marker haplotypes for molecular breeding of phosphorous deficiency tolerant rice varieties (Aluwihare Y.C., Chamikara M.D.M., Dissanayake D.R.R.P., Karunarathne S.I., Ananda G.K.S., Kannangara S.K., Madhukalpani O.V.S., Sirisena D.N., Samarasinghe W.L.G. \& Sooriyapathirana S.D.S.S.) 46: 495-504 (2018)

\section{River catchments}

Spatio-temporal variation of water quality and bio indicators of the Badulu Oya in Sri Lanka due to catchment disturbances (Gunawardhana W.D.T.M., Jayawardhana J.M.C.K., Udayakumara E.P.N. \& Malavipathirana S.) 46: 51-67 (2018)

\section{River health}

Spatio-temporal variation of water quality and bio indicators of the Badulu Oya in Sri Lanka due to catchment disturbances (Gunawardhana W.D.T.M., Jayawardhana J.M.C.K., Udayakumara E.P.N. \& Malavipathirana S.) 46: 51-67 (2018)

\section{Root systems growth}

Root growth responses of parthenium weed and different pasture plants under elevated atmospheric carbon dioxide (Khan N., Hanif Z., Khan I.A., Naveed K., Shabbir A. \& Adkins S.W.) 46: 303-310 (2018)

\section{Rough set}

Generalised roughness in ( $\in, \in \mathrm{Vq}$ )-fuzzy substructures of LA-semigroups (Rehman N., Shah N., Ali M.I. \& Ali A.) 46: 465-473 (2018)

\section{Rsol $\_$fiC}

Development of a rapid, sensitive and specific DNA-based method to detect Ralstonia solanacearum in potato for quarantine purposes (Perera A.A.U., Weerasena O.V.D.S.J., Dasanayaka P.N. \& Wickramarachchi D.C.) 46: 153-158 (2018)

\section{Sadhana index}

Some topological indices of the family of nanostructures of polycyclic aromatic hydrocarbons (PAHs) (Soleimani N., Mohseni E., Maleki N. \& Imani N.) 46: 81-88 (2018)

\section{Sclerotinia sclerotiorum}

Phenotypic variation of cabbage white mold pathogen, Sclerotinia sclerotiorum in the upcountry commercial cabbage fields in Sri Lanka (Mahalingam T., Guruge B.M.A., Somachandra K.P., Jayasekara E.A.E.S.S., Rajapakse C.S.K. \& Attanayake R.N.) 46: 159-164 (2018)

\section{Seed potato}

Development of a rapid, sensitive and specific DNA-based method to detect Ralstonia solanacearum in potato for quarantine purposes (Perera A.A.U., Weerasena O.V.D.S.J., Dasanayaka P.N. \& Wickramarachchi D.C.) 46: 153-158 (2018)

\section{Sensory evaluation}

Use of Mandel's bundle of lines model to improve agreement of a panel of tea tasters (Peiris T.U.S., Walgampaya C.K., Banks D.L., Thattil R.O. \& Abeysinghe I.S.B.) 46: 95-102 (2018) 
Shape adjustment

$C^{3}$ cubic trigonometric B-spline curves with a real parameter (Xie W. \& Li J.) 46: 89-94 (2018)

\section{Shot boundary detection}

Gradual transition detection in shot boundary using gradual curve point (Prabavathy A.K. \& Shree J.D.) 46: 393-398 (2018)

\section{Shuhui 527}

Development of heat tolerant introgression lines and preliminary quantitative trait loci (QTL) analysis at flowering stage in Oryza sativa L. (Udawela U.A.K.S., Ananda G.K.S., Karunarathne S.I., Sooriyapathirana S.D.S.S., Li F. \& Liu Z.) 46: 253-270 (2018)

\section{Simulation study}

Enhancing ratio estimators for estimating population mean using maximum value of auxiliary variable (Abbas N., Abid M., Tahir M., Abbas N. \& Hussain Z.) 46: 453-463 (2018)

\section{Soil moisture}

Growth responses of Lantana (Lantana camara L.) varieties to varying water availability and light conditions (Gunasekara C. J. \& Ranwala S.M.W.) 46: 69-79 (2018)

\section{Somaclonal variations}

Comparative morpho-physiological response of in vitro selected somaclones of wheat (Triticum aestivum L.) and explant donor parent to drought stress (Mahmood I., Razzaq A., Qureshi A.A., Qayyum A. \& Baig M.M.Q.) 46: 293-302 (2018)

\section{Sparse linear models}

Two-layer malicious network flow detection system with sparse linear model based feature selection (Catak F.O.) 46: 601-612 (2018)

\section{Sphericity}

Genetic analysis of yield and physical traits of spring wheat grain (Muhu-Din Ahmed H.G., Khan A.S., Kashif M. \& Khan S.H.) 46: 23-30 (2018)

\section{Sri Lanka}

Interpretation of gravity anomalies over the eighty-five East Ridge in the Bay of Bengal (Tantrigoda D.A. \& Fernando M.M.P.M.) 46: 487-494 (2018)

\section{Sri Lanka}

Prebiotic carbohydrate profile and in vivo prebiotic effect of pumpkin (Cucurbita maxima) grown in Sri Lanka (Lokuge G.M.S., Vidanarachchi J.K., Thavarajah P., Siva N., Thavarajah D., Liyanage R., Balasooriya N. \& Alwis J.) 46: 477-485 (2018)

\section{Sri Lanka}

Rediscovery of Tetragonula praeterita after 1860: an unremarked common stingless bee endemic to Sri Lanka (Silva T.H.S.E., Diyes G.C.P., Karunaratne W.A.I.P. \& Edirisinghe J.P.) 46: 109-113 (2018)

\section{Sri Lanka}

The forgotten tigers: the arboreal tiger beetles of Sri Lanka (Dangalle C.D.) 46:241-252 (2018)

\section{Sri Lankan marine algae}

Preliminary screening of two marine algae and sea grass harvested from Sri Lankan waters against the LPS-induced inflammatory responses in RAW 264.7 macrophages and in vivo zebrafish embryo model (Fernando I.P.S., Sanjeewa K.K.A., Samarakoon K.W., Lee W.W., Kim H.S., Kim E.A., Ranasinghe P., Gunasekara U.K.D.S.S., Premakumara G.A.S. \& Jeon Y.J.) 46: 117-124 (2018)

\section{Stem biomass}

Generic assumption vs. empirical model in stem carbon prediction of Eucalyptus grandis Wall ex. Maiden (Bandara W.A.R.T.W. \& Aththanayake A.M.H.L.) 46: 411-422 (2018)

\section{Stimulation}

Effect of ethephon stimulation on natural rubber latex properties; new insight into ethephon stimulation (Attanayake A.P., Karunanayake L. \& Nilmini A.H.R.L.) 46: 179-185 (2018)

\section{Stingless bees}

Rediscovery of Tetragonula praeterita after 1860: an unremarked common stingless bee endemic to Sri Lanka (Silva T.H.S.E., Diyes G.C.P., Karunaratne W.A.I.P. \& Edirisinghe J.P.) 46: 109-113 (2018)

\section{Stretching sheet}

Convective heat transfer in a dusty ferromagnetic fluid over a stretching surface with prescribed surface temperature/heat flux including heat source/ sink (Majeed A., Zeeshan A. \& Gorla R.S.R.) 46: 399-409 (2018)

\section{Submerged breakwaters}

Numerical modelling of wave transformation over submerged breakwaters using Boussinesq-type models (Ranasinghe R.S.) 46: 369-379 (2018)

\section{Sunspot}

Modelling the effects of solar activity on the ionospheric $\mathrm{F}_{2}$ critical frequency over Wakkanai (Mushtaq M., Afridi F.A.K., Alam S.N. \& Fatima H.) 46: $527-538(2018)$ 
Symmetric uncertainty

An optimal feature selection method using a modified wrapper-based ant colony optimisation (Jameel S. \& Rehman S.U.) 46: 143-151 (2018)

\section{Synthesis}

Synthesis and characterisation of two new bicyclic oxazolidines and investigation of their optoelectronic properties using density functional theory (Abbas G., Irfan A., Hameed S., Al-Sehemi A.G., Jin R. \& Tang S.) 46: 197-204 (2018)

\section{Syzygium cumini}

In vitro antiglycation and hypoglycaemic effects of Syzygium cumini leaf extracts (Perera H.K.I., Poongunran J., Premadasa W.K.V.K. \& Jayasinghe J.A.V.P.) 46: 281-291 (2018)

\section{Tasting panel}

Use of Mandel's bundle of lines model to improve agreement of a panel of tea tasters (Peiris T.U.S., Walgampaya C.K., Banks D.L., Thattil R.O. \& Abeysinghe I.S.B.) 46: 95-102 (2018)

\section{Tetragonula}

Rediscovery of Tetragonula praeterita after 1860: an unremarked common stingless bee endemic to Sri Lanka (Silva T.H.S.E., Diyes G.C.P., Karunaratne W.A.I.P. \& Edirisinghe J.P.) 46: 109-113 (2018)

\section{Textiles}

Colour fastness to washing of multi-layered digital prints on textile materials (Kašiković N., Vladić G., Milić N., Novaković D., Milošević R. \& Dedijer S.) 46: 381-391 (2018)

\section{Texture}

Genetic analysis of yield and physical traits of spring wheat grain (Muhu-Din Ahmed H.G., Khan A.S., Kashif M. \& Khan S.H.) 46: 23-30 (2018)

\section{Thermal degradation}

Kissinger method: the sequential approach and DAEM for kinetic study of rubber and gliricidia wood (Perera K.U.C. \& Narayana M.) 46: 187-196 (2018)

Theta index

Some topological indices of the family of nanostructures of polycyclic aromatic hydrocarbons (PAHs) (Soleimani N., Mohseni E., Maleki N. \& Imani N.) 46: 81-88 (2018)

Time dependent density functional theory

Snthesis and characterisation of two new bicyclic oxazolidines and investigation of their optoelectronic properties using density functional theory (Abbas G., Irfan A., Hameed S., Al-Sehemi A.G., Jin R. \& Tang S.) 46: 197-204 (2018)

\section{Time-dependent ROC curves}

Adaptation of the weighted Kaplan-Meier method to time-dependent ROC curves (Sigirli D., Ercan I., Balcin O. \& Kaya E.) 46: 11-21 (2018)

\section{$t$-implication-based fuzzy ternary subsemigroup}

Implication-based fuzzy ternary subsemigroups in ternary semigroups (Rehman N.) 46: 423-430 (2018)

\section{Toxic hazard identification}

Assessing toxicity of two industrial zone effluents reaching Kelani River, Sri Lanka (Hemachandra C.K. \& Pathiratne A.) 46: 539-546 (2018)

Traditional morphometrics

Morphometry as a tool in species identification: a study with special reference to species of the genus Mycalesis (Lepidoptera: Nymphalidae) (Goonesekera K., van der Poorten G. \& Ranawaka G.R.) 46: 311-328 (2018)

Trigonometric polynomial

$C^{3}$ cubic trigonometric B-spline curves with a real parameter (Xie W. \& Li J.) 46: 89-94 (2018)

Tukey

Estimation of genetic diversity in sorghum genotypes of Pakistan (Mumtaz A., Hussain D., Saeed M., Arshad M. \&. Yousaf M.I.) 46: 271-280 (2018)

Turbulent kinetic energy model

Numerical modelling of wave transformation over submerged breakwaters using Boussinesq-type models (Ranasinghe R.S.) 46: 369-379 (2018)

\section{Upper record values}

Record values of ratio of Weibull random variables (Al-Zahrani B., Shahbaz S.H. \& Shahbaz M.Q.) 46: 165-178 (2018)

\section{Urban impacts}

Spatio-temporal variation of water quality and bio indicators of the Badulu Oya in Sri Lanka due to catchment disturbances (Gunawardhana W.D.T.M., Jayawardhana J.M.C.K., Udayakumara E.P.N. \& Malavipathirana S.) 46: 51-67 (2018)

\section{Vulpinic acid}

The anti-genotoxic effect of some lichenic acids (Kizil H.E., Ceker S., Capik O. \& Agar G.) 46: $227-231$ (2018) 
Washing

Colour fastness to washing of multi-layered digital prints on textile materials (Kašiković N., Vladić G., Milić N., Novaković D., Milošević R. \& Dedijer S.) 46: 381-391 (2018)

Water balance

Influences of temperature and precipitation on soil moisture in Anuradhapura District (Nawagamuwa U.P., Hornberger G.M. \& Gunda T.) 46: 519$526(2018)$

Wavelets

Influences of temperature and precipitation on soil moisture in Anuradhapura District (Nawagamuwa U.P., Hornberger G.M. \& Gunda T.) 46: 519$526(2018)$

WebAllergen

WebAllergen: a web-based database for protein allergenicity prediction (Won S.Y., Baek J.H., Oh J.H., Lee G.S., Kim Y.H. \& Kim C.K.) 46: 233$236(2018)$

\section{Weibull distribution}

Record values of ratio of Weibull random variables (Al-Zahrani B., Shahbaz S.H. \& Shahbaz M.Q.) 46: 165-178 (2018)

\section{Weighted Kaplan-Meier}

Adaptation of the weighted Kaplan-Meier method to time-dependent ROC curves (Sigirli D., Ercan I., Balcin O. \& Kaya E.) 46: 11-21 (2018)

\section{White mold}

Phenotypic variation of cabbage white mold pathogen, Sclerotinia sclerotiorum in the upcountry commercial cabbage fields in Sri Lanka (Mahalingam T., Guruge B.M.A., Somachandra K.P., Jayasekara E.A.E.S.S., Rajapakse C.S.K. \& Attanayake R.N.) 46: 159-164 (2018)

\section{Wind power}

Collector cable design based on dynamic line rating for wind energy applications (Wijethunga A.H., Ekanayake J.B. \& Wijayakulasooriya J.V.) 46: $31-40(2018)$

\section{Wrapper method}

An optimal feature selection method using a modified wrapper-based ant colony optimisation (Jameel S. \& Rehman S.U.) 46: 143-151 (2018)

\section{Zebrafish}

Preliminary screening of two marine algae and sea grass harvested from Sri Lankan waters against the LPS-induced inflammatory responses in RAW 264.7 macrophages and in vivo zebrafish embryo model (Fernando I.P.S., Sanjeewa K.K.A., Samarakoon K.W., Lee W.W., Kim H.S., Kim E.A., Ranasinghe P., Gunasekara U.K.D.S.S., Premakumara G.A.S. \& Jeon Y.J.) 46: 117-124 (2018)

\section{$\alpha$-amylase}

In vitro antiglycation and hypoglycaemic effects of Syzygium cumini leaf extracts (Perera H.K.I., Poongunran J., Premadasa W.K.V.K. \& Jayasinghe J.A.V.P.) 46: 281-291 (2018)

$\alpha$-glucosidase

In vitro antiglycation and hypoglycaemic effects of Syzygium cumini leaf extracts (Perera H.K.I., Poongunran J., Premadasa W.K.V.K. \& Jayasinghe J.A.V.P.) 46: 281-291 (2018) 